\title{
Guiding Light Selections From the Holy Qur'an
}

\section{Comments by AbdulHamìd A. AbüSulaymän}

Translation

In the name of Allah, Most Gracious, Most Merciful.

1. Now the 'Ad behaved Arrogantly through the land, Against (all) truth and reason, And said: "Who is superior To us in strength? What! Did they not see that God, Who created them, Was superior to them In strength? But they Continued to reject Our Signs! Sürah Fusșilat (41:15)

2. Against them make ready Your strength to the utmost Of your power, including Steeds of war, to strike terror Into (the hearts of) the enemies, Of God and your enemies And others besides, whom Ye may not know, but whom God doth know.Whatever Ye shall spend in the Cause Of God, shall be repaid Unto you, and ye shall not Be treated unjustly. Sürah Al Anfál (8:60)

3. He said: "(The power) in which My Lord has established me Is better (than tribute): Help me therefore with strength (And labour): I will Erect a strong barrier Between you and them:

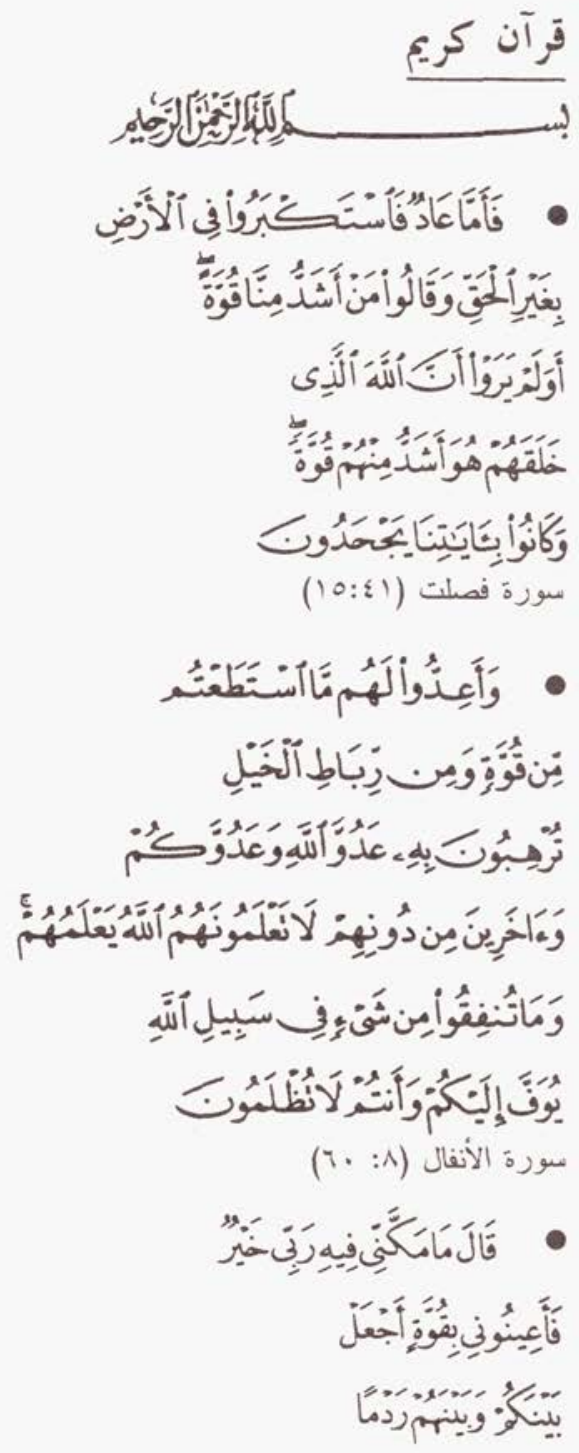


the Qur'an explains and applies the concept of power to wealth and children. We find that this use of a term followed by an explanation of its meaning and an illustration of its use in concrete terms is true in the rest of the verses quoted above. The important point that we would like to make in this commentary is that students of the social and human sciences should understand and appreciate the Qur'anic use of verbal nouns. They should look at them conceptually as areas of study, investigate them, and try to understand their scope, magnitude and application.

To make our point clear we will take a general look at the following verses:

10. Let not the Unbelievers

Think that they can

Get the better (of the godly):

They will never frustrate (them).

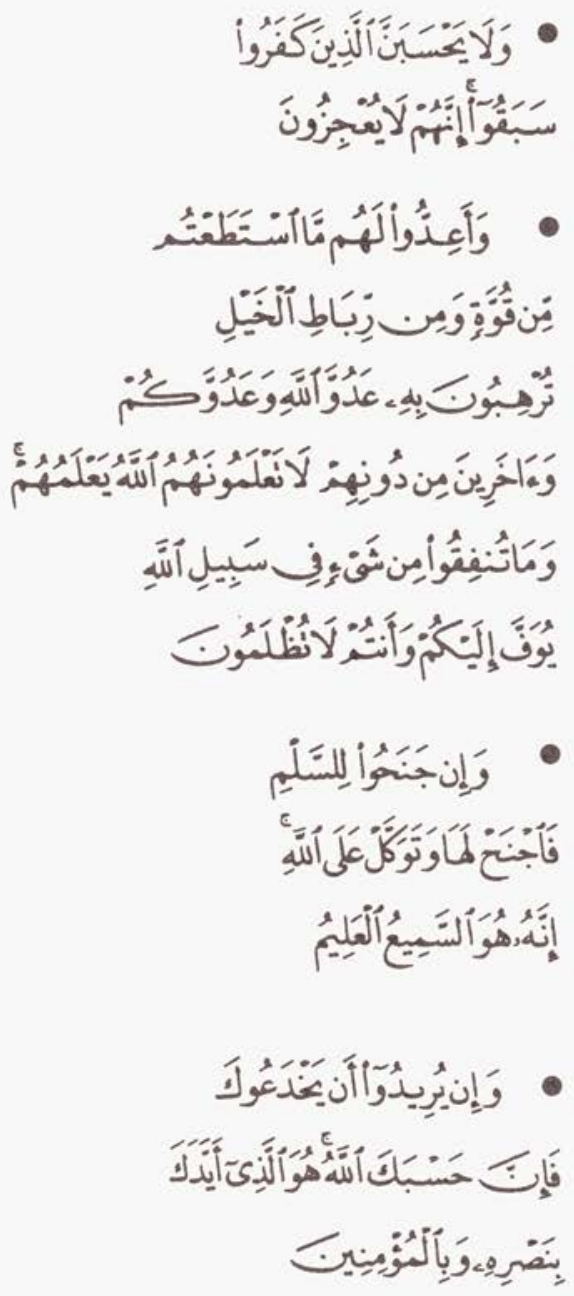

11. Against them make ready

Your strength to the utmost

Of your power, including

Steeds of war, to strike terror Into (the hearts of) the enemies, Of Allah and your enemies, And others besides, whom Ye may not know, but whom Allah doth know. Whatever Ye shall spend in the Cause Of Allah, shall be repaid Unto you, and ye shall not Be treated unjustly.

13. Should they intend

To deceive thee-verily Allah

Sufficeth thee: $\mathrm{He}$ it is

That hath strengthened thee

With His aid and

With (the company of)

The Believers;

14. And (moreover) He hath put Affection between their hearts: Not if thou hadst spent

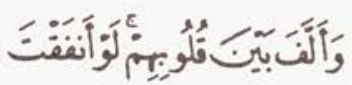


All that is in the earth,

Couldst thou have produced

That affection, but Allah

Hath done it: for $\mathrm{He}$

Is Exalted in might, Wise.

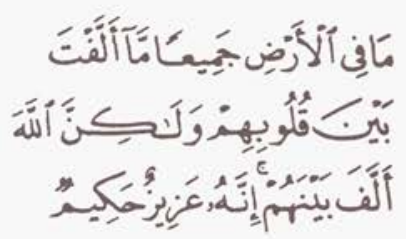

15. O Prophet! Sufficient

Unto thee is Allah-

(Unto thee) and unto those

Who follow thee

Among the Believers

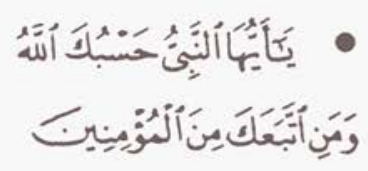

16. O Prophet! rouse the Believers

To the fight. If there are

Twenty amongst you, patient

And persevering, they will

Vanquish two hundred: if a hundred,

17. They will vanquish a thousand

Of the Unbelievers: for these

Are a people without understanding

18. For the present, Allah

Hath lightened your (task).

For He knoweth that there is

A weak spot in you:

But (even so), if there are

A hundred of you, patient

And persevering, they will

Vanquish two hundred, and if

A thousand, they will vanquish

Two thousand, with the leave

Of Allah: for Allah is with those

Who patiently persevere.

Sürah Al Anfal (8:59-66)

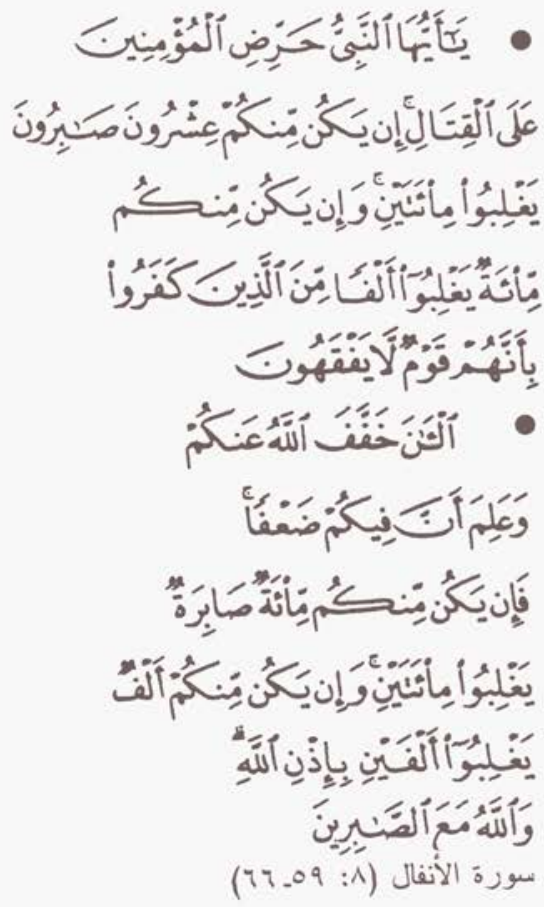

In these verses we find the Qur'anic discussion of power is in relation to war and confrontation. Looking at these verses we see that the Qur'an deals with aspects of physical power in terms of trained and ever-ready horses and cavalry as well as finance which were, in the time of the Prophet, very important components of military power. It also talks in terms of moral power-faith, solidarity and affection as well as patience and perseverance which are implied in the words al-mu'min, allafa and al-sabirin.

Looking closely at the last two verses (8:65-66) and referring to the classical works of jurisprudence (figh) and commentary on the Qur'an (taf$s \bar{r}$ ) by great scholars of the past such as Shafi'i in his book of jurisprudence, al-Umm and Ibn Kathïr in his book of commentary Tafsìr Ibn Kathïr, it is 
interesting to note that they did not pay much attention to the conceptual aspects of these verses related to power. The loss of power (daf) was the focus of their attention which they directed to the physical and operational aspects of the particular situation. That is why the conclusion they drew from their study and analysis of these verses was that Muslim fighters should not retreat and turn their backs on the enemy as long as they were no more than double the number of the Muslims. The emphasis here was on physical power, in particular the number of fighters.

In the contemporary world with our awareness of the concept of power and its numerous physical and moral components, applications, interrelations and dynamics, we can understand an additional dimension of these verses which actually emphasize the concept of power involved and the different components and dynamics that explain the change from a ratio of one to ten to a ratio of one to two. The reason for this great reduction in the ratio is the changes in the other components of power relationships between the Muslims and their enemies at a particular point in time.

In a conceptual study of these verses focusing on the concept of power it becomes clear that in fact these verses minimize the importance attached to the number of fighters and draw our attention to other factors of power; both the physical aspects of power such as armor, and the moral aspects such as faith and perseverance. Through pointing out the loss of the other factors of power (dafan) it shows that the number of fighters is of limited significance and the value and effectiveness of numbers could change drastically. In this case the ratio changes from one to ten to one to two. This is opposed to the conclusions of the jurists who emphasized the number of fighters, ignoring completely the other aspects of power.

The wider and more important lesson involved in this commentary is the importance of the conceptual study of the Qur'an and Sunnah. Muslim social scientists should give proper attention to concepts and theorization in their study of the Qur'an and Sunnah. They should study the application, interrelationship and dynamics of these concepts related to contemporary conditions and realities. The benefits and knowledge derived from the Qur'an and Sunnah would then be much more useful and functional. The functional and the operational dimensions are very much needed for any successful Muslim performance in the future.

The effects of the Muslim lack of attention to the theoretical and conceptual aspects of the Qur'an and Sunnah have been detrimental and because of this we have not been able to face changing situations and achieve an Islamic civilizational presence in the recent centuries.

It is important for Muslim scientists and intellectuals to pay attention to and carry out investigation and analysis on information, issues, principles and concepts of the revealed knowledge contained in the Qur'an and Sunnah. 
Muslim intellectuals have to study, understand, theorize and relate to their contemporary situation in order to better understand revealed knowledge and to avoid gross mistakes and great losses in order to attain wider and better horizons of human life and civilization.

\section{AMSS EXECUTIVE COMMITTEE $1989-1991$}

\section{PRESIDENT}

Dr. Mushtaqur Rahman 2817 Pinehurst Circle Ames, IA 50010

Off: (515) 294-6145/Res: 292-9398

\section{TREASURER}

Br. Mohammad AbuGideiri 4675 N. Gales Circle Fayetteville, NC 28314 Off: (919) 843-5942/Res: 8644863

\section{VICE PRESIDENT}

Dr. Salahuddin Malik

Chairman, Dept. of History

State Univ. of NY at Brockport

Brockport, NY 14420

Off: (76) 395-5692/Res: 244-6595

\section{MEMBER-AT-LARGE}

Dr. Nìmat $\mathrm{H}$. Barazangi

Dept. of Educ., Roberts Hall

Comell University

Ithaca, NY 14853-5901

Res: (607) 257-4199

\section{GENERAL SECRETARY}

Dr. Sayyid M. Syeed

555 Grove Street

Herndon, VA 22000

Off: (703) 471-1133/Res: 742-7986

\section{MEMBER-AT-LARGE}

Dr. Mahmoud Rashdan

555 Grove Street

Herndon, VA 22000

Off: (703) 471-1133/Res: $481-3138$

\section{AMSS DISCIPLINE HEADS \\ Discipline Council Chairpersons}

Discipline Council Coordinator:

Dr. M.A.W. Fakhri

7827 W. 165th Place

Tinley Park, IL 60477

Off: (312) 995-2004/Res: 532-5557

\section{Anthropology}

Dr. Muhammad Maruf

214 Lafayette Drive

Swedboro, NJ 08085

Res: (609) 467-3271

Geography and Ecology

Dr. Mushtaqur Rahman

2817 Pinehurst Circle

Ames, IA 50010

Off: (515) 294-6145/Res: 292-9398
Business Administration and Management

Dr. Ghouse Shareef

Acct. Dept., Rubel Sch. of Bus.

Bellarmine College

Louisville, KY 40205

Off: (501) 452-8446/Res: $429-6889$

\section{History}

Dr. Aftab A. Khan

299 Allenhurst Road

Buffalo, NY 14226

Res: (716) 834-0716
Harden \& Blanding Streets

Columbia, SC 29204

Off: (803) 253-5109/Res: 781-9502

Muslim-American Studies

Dr. Sulayman Nyang

PO. Box 701, Woodmour

Silver Spring, MD 20901

Off: (202) 636-7115/Res: (301) 622-1786

\section{Religion and Philosophy}

Dr. Mustansir Mir

Assist. Prof. of Islamic Studies

Dept. of Near Eastern Studies

University of Michigan

Ann Arbor, MI 48109

Res: (313) $664-4645$
Political Science

Dr. Mona Abul Fadl

555 Grove Street

Herndon, VA 22070

Off: (703) $471-1133$ ext. 262
Pychology

Dr. Hakim M. Rashid

10033 Campus Way South

Largo, MD 2077

Off: (202) 636-7121/Res: (301) 336-5121

\section{Sociology}

Dr. Ilyas Ba-Yunus

9 Alexandria Drive, Rt. 5

Cortland, NY 13045

Off: (607) 753-2475/Res: 753-64ll 